\title{
The Role of Fixed-Dome and Floating Drum Biogas Digester for Energy Security in Indonesia
}

\author{
Ibnu Budiman ${ }^{1 *}$ \\ ${ }^{1}$ Wageningen University and Research \\ 6708 PB Wageningen, The Netherlands
}

Received 22 June 2020; Accepted 12 August 2020

Available online 31 August 2020

\begin{abstract}
Since 2010, technological innovations for small-medium biogas digester in Indonesia were mainly dominated by two designs; 1 . fixed-dome digesters as a strong technology and proven in other developing countries, 2. the floating drum digester made of fiberglass as a suitable design for Indonesia's earthquake-prone geography. This study analyzes the effectiveness of these two-biogas technologies for energy security in the country, from the perspectives of stakeholders of biogas programs. The study draws on semi-structured interviews, reviews of policy and program reports and documentation, as well as academic literature. Data were collected from key institutions and other stakeholders related to biogas programs, e.g. ministries, local governments, businesses, civil society, and academics. These institutions provided their review on the effectiveness of fixeddome and floating drum biogas digester. This study found that the technological effectiveness and reliability of both biogas technological design are relatively the same. Both technological designs are found to have problems a few weeks after the installation in some regions. These issues were caused by a lack of enforcement to the standard of technological construction. In terms of contribution to energy security, both designs contribute to the sustainability, availability, and affordability aspects of the energy system in the country. The diversity of technological design supports the resilience of the energy system. As a way forward, more detailed monitoring and evaluation are required to check damaged biodigesters and maintain a good quality of construction of both designs, particularly in rural areas.
\end{abstract}

Keywords: fixed-dome, floating drum, biogas, biodigester, Indonesia

\section{Introduction}

Rapid economic growth in middle-income countries in the Global South has led to heavy dependence on fossil fuel for energy generation and rapidly rising carbon emissions (Verbong \& Loorbach, 2012). These trends go against global agreements and national policies and programs pushing for energy security. One of the strategies to strengthen energy security is the diversification of energy resources and decentralized energy system (Goldthau, 2014). In Indonesia, the household sector accounts for about $30 \%$ of energy consumption in the country (DEN, 2016). About $80 \%$ of energy consumption in the household sector comes from cooking and transportation activities. In terms of cooking, the common dominant sources are liquefied petroleum gas (LPG) and firewood (Figure 1). About 17\% of households still use firewood for cooking, 76\% utilize LPG, and 1.24\% utilize biogas digester (BPS, 2017; Budiman \& Smits, 2020). During COVID-19 lockdown, the use of LPG even increased to $23 \%$ in some regions (IESR, 2020). LPG domination shows the degree of diversity in energy resources for cooking is still low. This situation does not only threaten energy security but also the state of the environment and

\footnotetext{
*Corresponding author

E-mail address: budimanibnu26@gmail.com
} 
public health (Bond \& Templeton, 2011; Budiman et al., 2018). This situation may increase the complexity of global risk ${ }^{1}$ in the future.

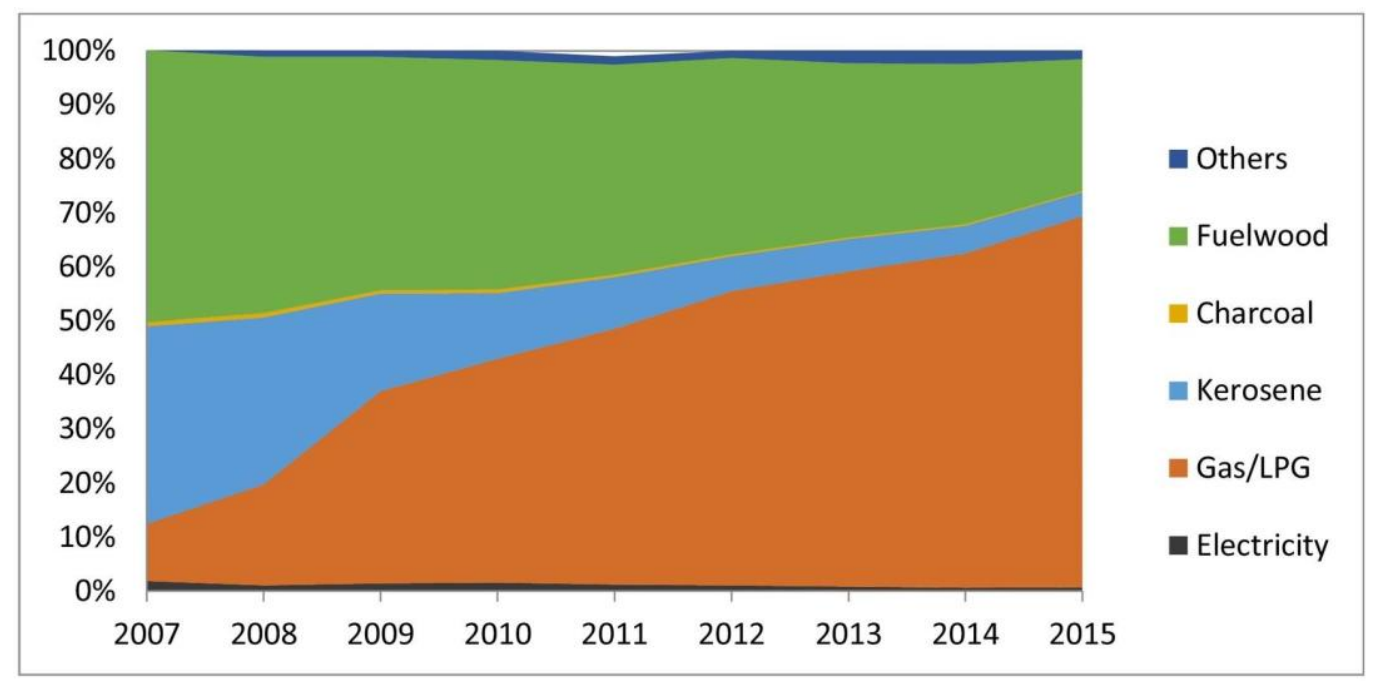

Figure 1. Percentage of households and their primary cooking fuel in Indonesia, 2007-2015 (Thoday et al., 2018).

To diversify energy resources related to cooking, biogas is considered a clean source that can be introduced, especially at the household level. Biogas technologies have been evolved in the Global South. Since 1929, China has been the world leader in biogas production (Bond \& Templeton, 2011). Furthermore, roughly 4 million biogas digesters are operating in India, whilst the use of biogas is also increasing in Vietnam, Brazil, and Tanzania (Bond \& Templeton, 2011; Rupf et al., 2015). In Indonesia, biogas digesters (or biodigesters) have been promoted by different actors over the last few decades, using different technological innovations, financial approach, and promotion strategies (Transrisk, 2017).

Since 2010, technological innovations for biodigester in Indonesia were somehow divided into two designs: 1) Fixed-dome digesters as a strong technology and proven in other developing countries, 2) Floating drum (fiberglass) digester type as more suitable design for Indonesia's earthquake-prone geography (Budiman \& Smits, 2020). This study analyzes the effectiveness of these two-biogas technologies for energy security in the country.

\section{Method}

This study draws on semi-structured interviews, reviews of policy and program reports and documentation, as well as academic literature (Figure 2). It includes both quantitative and qualitative data, followed by a series of analyses concerning the research objective. In this study, the focus is on the technological innovations in Indonesia biogas programs for households and groups (such as farmers groups). These households utilize small-scale biodigesters with a size of 4-12 $\mathrm{m}^{3}$ and the groups utilize medium-scale biodigester, sized about $20-100 \mathrm{~m}^{3}$.

Data for this study were collected from key institutions of biogas programs and other related stakeholders, e.g. ministries, local governments, businesses, civil society organizations, and academics. The representative from those institutions provided their review on the effectiveness of fixed-dome and floating drum biogas digester. A total of $25 \mathrm{semi}$-structured interviews were conducted from May to July 2018. The interviews utilized a purposive and snowball sampling technique to select key persons

\footnotetext{
${ }^{1}$ Pandemic is one of top ten global risks that may increase in the future. This suggests the increased frequency of lockdown and the increase of LPG usage.
} 
(1-2 people) from the key institutions and its related stakeholders. For the interview questions, the topic list from the research objective was utilized to guide the interviews. The emphasis was on questions about the effectiveness of two types of biogas technological innovation for energy security. Each interview had a duration of approximately one to two hours and was carried out face-to-face, mostly in the offices of the respective institutions. During each interview, policy and program reports; as well as documentation regarding biogas programs were requested from each stakeholder, to be reviewed for triangulation.

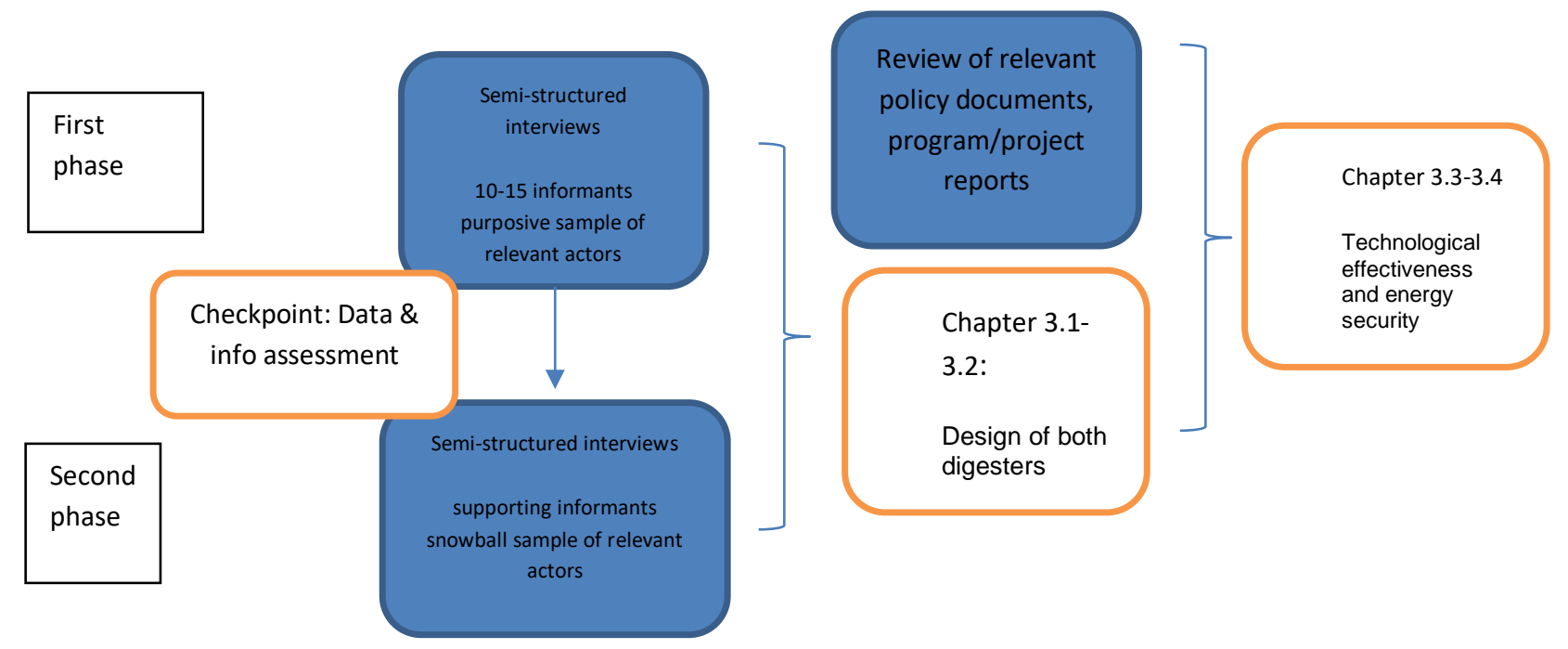

Figure 2. Data collection process and analysis.

After collection, all data were organized to prepare the structure of the evidence. Depending on the nature of the data, they were transcribed (in case of interviews), scanned (in case of document and literature review), or typed up (in case of other field notes). Later, for a more detailed analysis, a coding process was undertaken. The first coding session was done on the interview transcripts, policy documents, and program/project reports to analyze technological effectiveness from each biogas technological design. Afterward, the second round of coding was done to analyze the relationship between the effectiveness of each technology with energy security.

\section{Results and Discussion}

The biogas programs for households and (farmers) groups have been established in Indonesia since 2007 in four national-level institutions which are; the Ministry of Energy and Mineral Resources (MEMR), the Ministry of Agriculture (MA), the Ministry of Environment and Forestry (MEF), and Hivos (an international NGO). Both technologies of fixed-dome and floating drum biogas digester are found on those biogas programs.

\subsection{Design of Fixed Dome Digester}

The fixed-dome reactor design is an adaptation of existing systems used in other countries such as Bangladesh, Cambodia, Laos, Pakistan, Nepal, and Vietnam. This fixed-dome reactor is made from masonry and concrete work concealed underground. The system is proven to be environmentally friendly. In Nepal, this technology is used in over 200,000 households for more than 15 years, with $95 \%$ of the reactors currently still functioning (Bedi et al., 2017). 


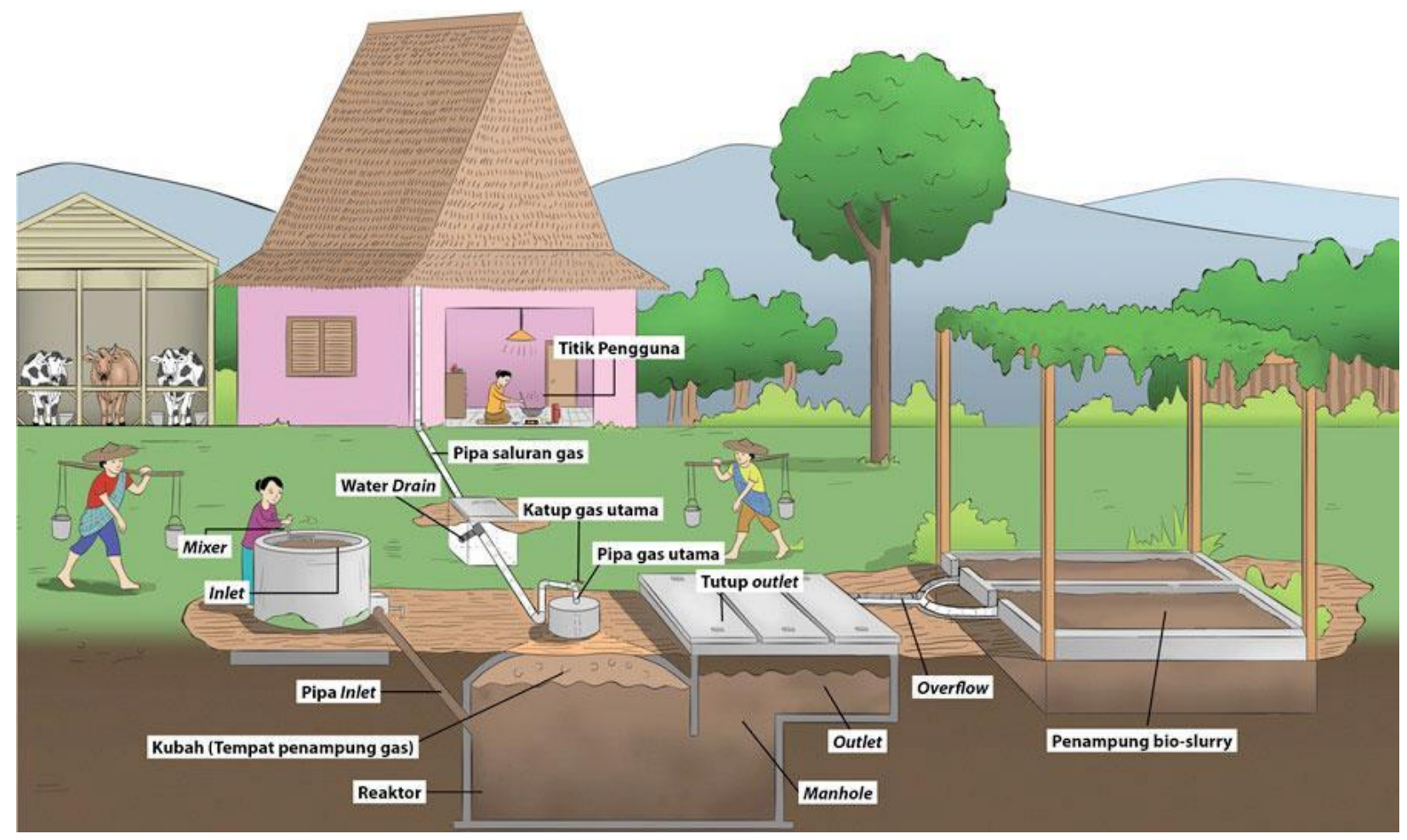

Figure 3. Design of fixed dome digester (BIRU, 2019)².

The fixed dome biogas plant has a minimum lifetime of 15 years if properly used and maintained. Maintenance is easy, it merely requires the occasional checking and - if necessary - repair of pipes and fittings. To operate one unit, the farmer needs to have at least 2 cows or 7 pigs (or a flock of 170 poultry) to produce enough feed for the reactor to be able to generate sufficient gas to meet their daily basic cooking and lighting needs (Bedi et al., 2012).

Table 1 shows the input and output configuration of fixed dome biodigester in different sizes. The expected amount of gas produced each day is considered as the plant capacity or plant size. Biogas production can be reported in this way because the feedstocks used in Indonesia usually do not change very much, leading to a predictable daily production level (IRENA, 2016).

Figure 3 shows that there are 6 main parts to the digester: Inlet (mixing tank) where animal dung is inserted to feed the digester, reactor (anaerobic/non-oxygenated digester chamber), gas storage (storage dome), outlet (divider chamber), gas carrier system and the bio-slurry pit or the compost pit for animal dung which has been reduced of any gas (deducted of all gases) (Alam, 2013).

Table 1. Input and output of biogas production using fixed dome digester with different sizes of the reactor (BIRU, 2019).

\begin{tabular}{l|lllll} 
Reactor size $\left(\mathrm{m}^{3}\right)$ & 4 & 6 & 8 & 10 & 12 \\
\hline The number of cow & $2-3$ & $4-5$ & 6 & $7-8$ & 9 \\
Volume of manure (kg/day) & 30 & 45 & 60 & 75 & 90 \\
Produced gas $\left(\mathrm{m}^{3}\right)$ & 1 & 1.5 & 2 & 2.5 & 3 \\
Duration of stove usage (hour) & 4 & 6 & 8 & 10 & 12
\end{tabular}

\footnotetext{
${ }^{2}$ This model generally consists of the following parts, which is also shown in the attached diagram sketch: Inlet (mixing tank), Inlet Pipe (adaptable to be connected to the toilet), Digester, Gas Storage (Dome), Manhole, Outlet \& Overflow, Main Gas Pipe and Turret, Main Gas Valve, Pipeline, Waterdrain, Pressure Gauge, Gas Tap, Gas Stove with with a rubber hose pipe, Lamp (option), and Bio-Slurry Pit
} 
The biogas reactor works by combining a mixture of feces and water (which takes place in the inlet or the mixing tank) flows through the pipeline towards the digester. The mixture produces gas, through a process of digestion that takes place in the reactor and is then stored in the gas storage chamber (upper side of the dome). The slurry flows out from the digester towards the outlet and results in what we know as bio-slurry that passes through the overflow outlet and is flowed into the slurry pit. Gas is later transported to the kitchen through the pipeline (Osak et al., 2015).

\subsection{Design of Floating Drum Digester}

The floating drum design for biogas digester consists of an underground digester (cylindrical or domeshaped) and a moving gas-holder. The gas-holder floats either directly on the fermentation slurry or in a water jacket of its own. The gas is collected in the gas drum, which rises or moves down, according to the amount of gas stored. The gas drum is prevented from tilting by a guiding frame. When biogas is produced, the drum moves up and when it is consumed, the drum goes down. If the drum floats in a water jacket, it cannot get stuck, even in the substrate with high solid content (Sathish \& Vivekanandan, 2016).
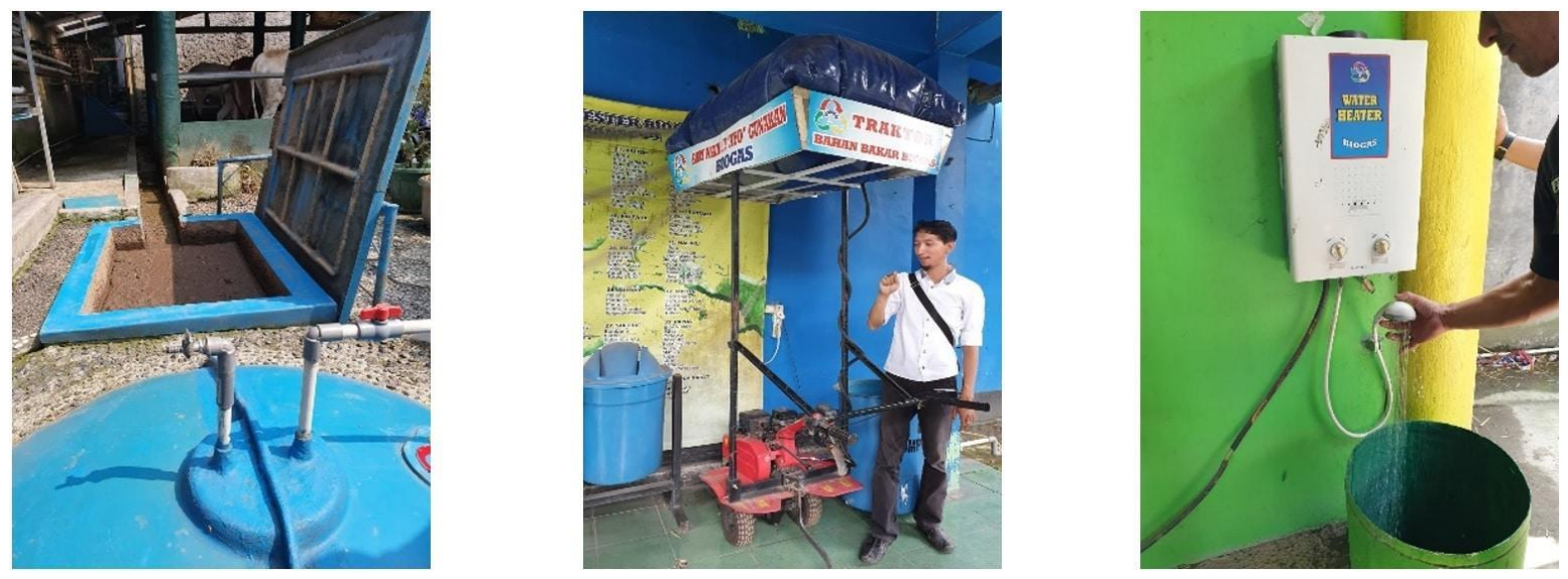

Figure 4. (Left) Floating drum biogas plants made of fiberglass, (Middle) Tractor using biogas; (Right) Water heater using biogas (PYC, 2019).

There are several types of floating-drum biogas plants. One of them is made of fiberglass reinforced polyester (Yadhunath, 2013). This type is the one utilized by the MA, made by the SWEN company (Figure 4). This biogas reactor involves both the inputs needed for the reactor and the expected output. The main input for the biogas reactor is cow manure, which can be combined with chicken or sheep manure as well as organic food waste. Human manure can also be used as an input if it does not mix with soap water. The combination of these inputs will influence the quality of the biogas that can be produced with cow manure as the best input. In addition to the biogas, the formed slurry can be utilized as an organic fertilizer. To compete with the existing fertilizer in the market, husk charcoal, eggshell, and farm lime must be added into the fertilizer to improve its quality (PYC, 2019).

SWEN company produces biogas reactors in various sizes and can be adjusted to the demand as well. The fiberglass floating drum by SWEN has a wider and higher range of capacities ${ }^{3}$ of its biodigester plant, which are from 4-100 $\mathrm{m}^{3}$. The $4 \mathrm{~m}^{3}$ biogas reactor is suitable for 2 cows and a $16 \mathrm{~m}^{3}$ biogas reactor is suitable for 25 cows. The $4 \mathrm{~m}^{3}$ biogas reactor from SWEN company requires an $18 \mathrm{~m}^{2}$ land area, for the whole reactor design.

The quality of inputs into the reactor and the local area characteristics (existence of landslide) could affect the biogas reactor lifetime. Normally, if there is no problem, then the expected lifetime of this biogas reactor is around 30 years (Cheng et al., 2014).

\footnotetext{
${ }^{3}$ Compared to the fixed dome biodigester
} 


\section{3 (Technological)Effectiveness of the Fixed-Dome and the Floating Drum Digester}

In this section, effectiveness analysis was conducted based on the adoption of the fixed-dome and the floating drum digester by different biogas programs/institutions. These institutions provided their review on the technological performance of both biodigester designs.

\subsubsection{Review for the Fixed-Dome Digester}

For the fixed-dome digester, this design is dominantly utilized by biogas programs from the Ministry of Energy and Mineral Resources (MEMR) and Hivos in partnership with YRE (a national NGO). These programs worked with local governments and community organizations such as farmers cooperatives. In a farmers' cooperatives in West Java, the fixed dome digester was introduced in the area from 2009. This technology was used by the farmers for cooking and electricity to some extent. The user found that the fixed dome digester is well functioned, and many farmers are interested in using it. The farmers argued that this technology was better than the previous plastic biogas reactor introduced by the government. But some farmers also found that their fixed dome digester was still broken. Hivos argued that this situation was caused by some construction partner organizations (CPOs) who did not follow detailed standards for the installation. The farmers were trying to ask the CPO to fix the digester, but the CPO asked for a renovation fee. Some farmers did not want to pay for it because it costs IDR 1.7 million.

In addition to the partnership scheme above, the provincial energy agency also had its own biogas program and adopted the fixed dome digester. In West Java, the provincial energy agency had utilized the fixed dome digester since 2010. In 2018, the agency evaluated the lifetime from the fixed dome biodigester, and they found that this reactor is the potential to diversify energy resources, especially for cooking.

Besides in the MEMR, the Ministry of Agriculture (MA) also utilized the fixed dome digester in one of their biogas programs such as the Batamas program. Batamas used the fixed dome in combination with various types of the digester, including the fixed dome. The MA spent about IDR 40 million per biogas digester unit. The money was delivered through local government that worked with the construction partners. Batamas utilized decentralized governance arrangement, with the interaction between the MA, local government, farmers, and construction partners. The MA claimed that Batamas triggered farmers to be productive in doing waste management in the farms.

Through Batamas, the farmers realized the benefit of biogas as a side income and additional energy supply. Therefore, they continued using the biodigester. The farmers were also provided with knowledge through the provision of training about the use of the digester. The training was conducted by the local research center under the MA. Both training and biodigester were disseminated for free for the farmers in about 50-60 biodigesters per year. However, the problem with the grant is that it makes the farmers do not have a sense of belonging to the biodigester. So, when the biodigester was broken, many farmers just left it without an effort to find a way to fix it. After the program finished, some farmers continued by installing biogas reactors by themselves. They installed a biogas plastic container with the lower cost, about IDR 2 million.

Later, The MA mentioned that they did not want to have a partnership with Hivos because the fixed dome digester was more expensive and not suitable for earthquake regions due to its fixed construction that is not flexible. The MA argued that earthquakes can cause some damages to the digester and the reparation cost is expensive.

Another institution that adopted the fixed dome digester is a provincial agriculture agency in Bali. They utilized the digester for their Simantri (integrated agriculture) program (Anugrah et al., 2014). This program utilized direct assignment financial schemes and partnership with Hivos and YRE. Simantri 
used the $4 \mathrm{~m}^{3}$ reactor. Previously, this program utilized the fiberglass floating drum design. After some issues, the agency replaced biogas digester with the fixed dome. The fiberglass floating drum often had problems and had a short lifetime.

Additionally, the Ministry of Environment and Forestry (MEF) also adopted the fixed dome biodigester. The MEF adopted the fixed dome for some biogas programs. However, there was no specific report and review from the ministry, due to a lack of monitoring and evaluation of the programs.

The use of fixed-dome in many biogas programs in different ministries makes this technology contributed to establishing the national standard in Indonesia for fixed-dome biodigester. In 2012, the decision was taken on the MEMR meeting about SNI (Indonesian national standard) for biogas digester. The standards were discussed with private sectors and NGOs. This standard is adopted by the MEMR to be applied to other biogas programs, especially biogas programs by the MEMR that uses SAF (Special allocation fund). The MEMR has been using the technological standards of the fixed dome to recruit vendors or to open tender for biogas programs. Until 2017, 24,723 units of fixed dome biodigester (with a range of plant capacity from 4-12 $\mathrm{m}^{3}$ ) had been installed all over Indonesia, from different biogas programs by different institutions (MEMR, 2018).

The technological standard for biodigester is updated every year. The standard included the criteria for specifications of biodigester technology and technical guideline for installing biodigester. The MEMR used to invite Hivos and YRE for drafting the biogas standards, together with other representatives of biogas actors, such as PT SWEN with their fiberglass floating drum design.

\subsubsection{Review for the Fiberglass Floating Drum}

The floating drum design with fiberglass in Indonesia was developed by the SWEN company. This company develops this biogas technology and its derivation to achieve the vision of energy sovereignty in Indonesia.

With fiberglass, the company can use a knockdown system for installing a digester and it is movable. This technology is certified by SNI 702, proven by the report of the test in PPMEKTAN (government research center or Balai pengujian). The price of this design is almost the same as the fixed dome digester. Beside produced for households, fiberglass is also produced on a large scale for industries such as palm oil.

SWEN company argues that the use of biodigester must adapt to different types of soil geography in Indonesia. The fiberglass floating drum design is suitable for many Indonesian regions that are vulnerable to earthquakes. The fiberglass design is resilient to earthquakes and easy to fix when there is an operational problem. The fiberglass design is dominantly utilized by the Ministry of Agriculture (MA). The MA found that the fiberglass digester is better than a fixed dome that has problems in the Batamas program. Until 2017, 11,308 fiberglass biodigesters (with a range of plant capacity from 4$100 \mathrm{~m}^{3}$ ) have been disseminated in many provinces in Indonesia (MEMR, 2018).

According to an NGO construction partner organization in Bandung-West Java, local public work agency also adopted the fiberglass biodigester for some neighborhoods. The energy feedstock is a domestic waste. However, the reactor worked only a few times. The issue was because of a lack of standard enforcement in the construction. The construction vendor was not properly trained, they learned from the guideline from the online module, conducting observation, and trial and error in construction implementation.

The same issue is also found in the corporate social responsibility (CSR) biogas program that subsidized 100 fiberglass biodigesters in 2009-2010 for the community along the Citarum river, from Subang to Lembang, West Java. According to a civil society organization in the area, the use of fiberglass design 
in the program was also not successful. The program stopped because the technology was broken. YRE argues that fiberglass design often has problems and has a short lifetime.

\subsection{Effectiveness for Energy Security}

Energy security is related to the quantity and quality of both technological designs. High quantity with wide distribution and good quality of technological performance contributed to increasing energy security in the country. Improvement of these points on the fixed dome and the fiberglass floating drum will contribute to boosting energy security in Indonesia. The energy security conundrum is about how to equitably provide available, affordable, reliable, efficient, and environmentally benign energy services. This relates not only to technology but also to policy aspects (Sovacool, 2011).

\subsubsection{Reliability and Affordability}

The findings above show that each design either the fixed-dome or the fiberglass floating drum has its unique strengths and weaknesses (Table 2). According to livestock agency in Bandung, the fiberglass design could last longer, but the issue is that this design requires a large area while some farmers do not have it. For the fixed dome, the problem is that not all land characteristics suit the design.

Previous research found that the floating drum plants became obsolete as they have high investment and maintenance costs along with other design weaknesses (Yadhunath, 2013). According to the research center in the MEMR, the fiberglass design may have longer durability in earthquake vulnerable regions, but its technological effectiveness is the same as the fixed dome.

Some units of both technologies were found broken due to a lack of standard enforcement in the implementation of installation. Some biogas programs and government actors tend to look for partners/vendors who can be paid at low cost, thus installing cheap biogas design with low standards. Some actors argue that the fixed dome digester is more expensive than the fiberglass.

Table 2. Comparing the role of fixed dome digester with fiberglass floating drum digester for energy security.

The unique
characteristic of
technological design
Range of plant capacity
Technological
effectiveness

\section{Estimated}

dissemination number

from 2011-2017

Adoption in biogas

programs

Contribution to energy security
Fixed dome digester

Fixed, concrete plant

4- $12 \mathrm{~m}^{3}$

Medium, having issues a few weeks after the installation in some places due to lack of enforcement to the standard of technological construction

24,723 units

BIRU, MEMR, Local governments

To sustainability, availability, affordability, and knowledge/skill/technological transfer
Fiberglass floating drum digester Flexible/movable, adaptive to earthquake

\section{4-100 $\mathrm{m}^{3}$}

Medium, having issues a few weeks after the installation in some places due to lack of enforcement to the standard of technological construction

11,308 units

Ministry of Agriculture, Local governments, CSR

To sustainability, availability, and affordability

The fiberglass design is developed by SWEN company that is faster in technology development, but lacks monitoring technicians. While the fixed dome by Hivos had trained hundreds of local organizations to be builders and technicians for biogas installation. Hivos utilized this approach to make local people/groups able to build digester on their own. This makes the dissemination of the fixed-dome 
design higher than the fiberglass floating drum. But SWEN argues that it is not easy because it is related to the issue of quality of construction that must be controlled.

\subsubsection{Availability}

Policy and governance in a decentralized energy system support energy security (Budiman \& Smits, 2018). Having diversity in energy resources and its technological design can support the resilience of the energy system in a country (Bostan et al., 2012). When one of the technological designs has problems, then energy supply can still be derived from another design. This also applies to renewable energy systems that are playing an important role in the current discourse on energy security and sustainability. Scientific, engineering, and economic solutions are adopted as a constant effort to understand mechanisms and options to allow a faster penetration to the governance of energy transition. Knowledge is one of the important resources in supporting the governance of energy transition and security (Budiman, 2018; Transrisk, 2017).

In the case study of biogas governance in Indonesia, the power of knowledge about biogas technology is acquired by the field implementing agencies such as Hivos, YRE, its CPOs, and SWEN company. They are some of the limited players for biogas digester producers in the country. There are only about 3-4 companies besides them.

Hivos and YRE have disseminated techno-scientific information to their CPOs (local organizations) in ten provinces in Indonesia, through various training. It makes CPOs have capable personnel that own knowledge and experience in biodigester technology and its installation. Local organizations need to have the capacity to boost local energy resilience (Ismail et al., 2019). The decentralization of knowledge supports wide adoption of the fixed dome digester, thus contributing to energy security.

On the other side, decentralized knowledge is not matched with the business logic of SWEN as a company. Therefore, the SWEN company centralizes its biogas-related knowledge of the fiberglass floating drum. SWEN company chooses to centralize their knowledge expertise, for their dissemination in 30 provinces in Indonesia. This centralized approach may not support wide technological adoption for energy security because technical capacity is not widely disseminated to local people/organizations. But it may support energy security in terms of providing biodigester with controlled quality and performance.

The centralized approach has its own risk. Once SWEN has issues such as bankruptcy, dissemination of the fiberglass floating drum may be stopped. The centralization of knowledge is related to the distribution of available knowledgeable personnel to disseminate/diffuse the use of technology.

\section{Conclusion}

This study found that the technological effectiveness and reliability of both biogas technological design (fixed-dome and fiberglass floating drum) are relatively the same. Both technological designs are found to have problems a few weeks after the installation in some places. This problem was caused by a lack of enforcement to the standard of technological construction. Despite its same technological effectiveness, the fixed-dome design is utilized more in many biogas programs. This is because a more advanced dissemination approach for the fixed dome implemented by Hivos and partners that makes this design is more popular for some government institutions and local partners. While for the fiberglass floating drum design, despite its lower number $(11,308)$ of unit dissemination, wider and higher range of capacities $\left(4-100 \mathrm{~m}^{3}\right)$ of its biodigester plant makes the gas production almost the same with the fixed dome digesters who have a higher number of dissemination unit $(24,723)$ but lower plant capacity (4$\left.12 \mathrm{~m}^{3}\right)$.

The existence of both technological designs increases the availability of energy reactor. A slightly different price/cost in both designs also makes biogas reactor becoming more affordable for more 
people and groups in a wider range of income. Besides, both technologies provide environmentally benign energy services. These aspects of sustainability, availability, and affordability make both designs contribute to energy security in Indonesia.

In terms of decentralized knowledge to support energy security, the fixed-dome design by Hivos is found performing better than the fiberglass floating drum by SWEN. Training by Hivos and YRE to local organizations have transferred technoscientific knowledge of the fixed-dome digester to local people/organizations and make them able to install the reactor by themselves. In this case, SWEN should consider disseminating their technoscientific knowledge to local companies/partners to enable wide adoption of the fiberglass floating drum design, to support energy security.

As a way forward, either the fixed-dome and fiberglass floating drum still needs to be developed more to increase its technological effectiveness. More detailed monitoring and evaluation is also required to check damage biodigesters and maintain a good quality of construction of both designs, on the ground. Further research is required for the energy efficiency of both types of the biodigester. Moreover, other energy actors are encouraged to keep improving design innovation for diversifying energy technologies to support energy security.

\section{References}

Alam, M. (2013). Bringing the blue flame home: Investigating successful implementation of household biogas program ('BIRU') in Bantul Regency, Yogyakarta Province from the view of co-evolutionary framework. Seminar Nasional Manajemen Teknologi XVIII, Surabaya.

Anugrah, I. S., Sarwoprasodjo, S., Suradisastra, K., \& Purnaningsih, N. (2014). Sistem pertanian terintegrasi - Simantri: Konsep, pelaksanaan, dan perannya dalam pembangunan pertanian di Provinsi Bali. Forum penelitian Agro Ekonomi, 32(2), 157-176. Retrieved from: https://doi.org/10.21082/fae.v32n2.2014.157-176

Bedi, A., Benscha, G., Niemanna, R., Peters, J., Sparrow, R., \& Tasciotti, L. (2012). Impact evaluation of the Indonesia domestic biogas programme. Rheinisch-Westfälisches Institut Für Wirtschaftsforschung, Essen, German and International Institute of Social Studies, Erasmus University, Rotterdam, The Netherlands.

Bedi, A., Sparrow, R., \& Tasciotti, L. (2017). The impact of a household biogas programme on energy use and expenditure in East Java. Energy Economics, 68, 66-76.

BIRU. (2019). Reaktor biogas - biogas rumah. Retrieved from: http://www.biru.or.id/reaktor-biogas

Bond, T., \& Templeton, M. R. (2011). History and future of domestic biogas plants in the developing world. Energy for Sustainable Development, 15(4), 347-354.

Bostan, I., Gheorghe, A. V., Dulgheru, V., Sobor, I., Bostan, V., \& Sochirean, A. (2012). Resilient energy systems: Renewables: Wind, solar, hydro. Springer Science \& Business Media.

BPS. (2017). Persentase-rumah-tangga-menurut-provinsi-dan-bahan-bakar-utama-untuk-memasaktahun-2001-2007-2016. Retrieved from: https://www.bps.go.id/statictable/2014/09/10/1364/persentase-rumah-tangga-menurut-provinsidan-bahan-bakar-utama-untuk-memasak-tahun-2001-2007-2016.html.

Budiman, I. (2018). Enabling community participation for social innovation in the energy sector. Indonesian Journal of Energy, 1(2), 21-31-21-31.

Budiman, I., Muthahhari, R., Kaynak, C., Reichwein, F., \& Zhang, W. (2018). Multiple challenges and opportunities for biogas dissemination in Indonesia. Indonesian Journal of Energy, 1(2), 46-60-4660 .

Budiman, I., \& Smits, M. (2020). How do configuration shifts in fragmented energy governance affect policy output? A case study of changing biogas regimes in Indonesia. Sustainability, 12(4), 1358. Retrieved from: https://doi.org/10.3390/su12041358

Budiman, I., \& Smits, M. M. (2018). The tangled thread: Fragmentation of biogas governance in Indonesia. 
Cheng, S., Li, Z., Mang, H.-P., Huba, E.-M., Gao, R., \& Wang, X. (2014). Development and application of prefabricated biogas digesters in developing countries. Renewable and Sustainable Energy Reviews, 34, 387-400.

DEN. (2016). Indonesia energy outlook 2016. Sekretariat Jenderal Dewan Energi Nasional.

Goldthau, A. (2014). Rethinking the governance of energy infrastructure: Scale, decentralization and polycentrism. Energy Research \& Social Science, 1, 134-140.

IESR. (2020). Energi untuk memasak selama \#dirumahaja: Tetap nyaman dengan energi bersih terbarukan. IESR. Retrieved from:

http://iesr.or.id/energi-untuk-memasak-selama-dirumahaja-dirumahajaaman-memasak-tetapnyaman-dengan-energi-bersih-terbarukan/

IRENA. (2016). Measuring small-scale biogas capacity and production. 36.

Ismail, C. J., Takama, T., Budiman, I., \& Knight, M. (2019). Comparative study on agriculture and forestry climate change adaptation projects in Mongolia, the Philippines, and Timor Leste. In P. Castro, A. M. Azul, W. Leal Filho, \& U. M. Azeiteiro (Eds.), Climate Change-Resilient Agriculture and Agroforestry: Ecosystem Services and Sustainability (pp. 413-430). Springer International Publishing. Retrieved from: https://doi.org/10.1007/978-3-319-75004-0_24

MEMR. (2018). Realisasi program biogas. Ministry of Energy and Mineral Resources Indonesia.

Osak, R., Hartono, B., Fanani, Z., \& Utami, H. D. (2015). Biogas and bioslurry utilization on dairyhorticulture integrated farming system in Tutur Nongkojajar, District of Pasuruan, East Java, Indonesia. Livestock Research for Rural Development, 27(4), 65.

PYC. (2019). PYC field study: Biogas reactor at PT Swen Inovasi transfer in Ciomas, Bogor. The Purnomo Yusgiantoro Center. Retrieved from: https://www.purnomoyusgiantorocenter.org/2019/05/15/pyc-field-trip-report-biogas-reactor-at-ptswen-inovasi-transfer-in-ciomas-bogor/

Rupf, G. V., Bahri, P. A., de Boer, K., \& McHenry, M. P. (2015). Barriers and opportunities of biogas dissemination in Sub-Saharan Africa and lessons learned from Rwanda, Tanzania, China, India, and Nepal. Renewable and Sustainable Energy Reviews, 52, 468-476.

Sathish, S., \& Vivekanandan, S. (2016). Parametric optimization for floating drum anaerobic biodigester using response surface methodology and artificial neural network. Alexandria Engineering Journal, 55(4), 3297-3307.

Sovacool, B. K. (2011). Evaluating energy security in the Asia Pacific: Towards a more comprehensive approach. Energy Policy, 39(11), 7472-7479. Retrieved from: https://doi.org/10.1016/j.enpol.2010.10.008

Thoday, K., Benjamin, P., Gan, M., \& Puzzolo, E. (2018). The mega conversion program from kerosene to LPG in Indonesia: Lessons learned and recommendations for future clean cooking energy expansion. Energy for Sustainable Development, 46, 71-81. Retrieved from: https://doi.org/10.1016/j.esd.2018.05.011

Transrisk. (2017). Report on social discourse analyses and social network analyses. Retrieved from: https://europa.eu/capacity4dev/public-energy/documents/transrisk-report-report-social-discourseanalyses-and-social-network-analyses

Verbong, G., \& Loorbach, D. (2012). Governing the energy transition: Reality, illusion or necessity?. Routledge.

Yadhunath, K. K. (2013). Move off the grid. Partridge Publishing. 